\title{
Aridification of the Egyptian Sahara 5000-4000 cal BP revealed from x-ray fluorescence analysis of Nile Delta sediments at Kom al-Ahmer/Kom Wasit
}

\author{
Benjamin T. Pennington ${ }^{\mathrm{a}, \mathrm{b}, *}$ \\ Mohamed A. Hamdan ${ }^{c}$ \\ Ben R. Pears ${ }^{\text {a }}$ \\ Hamed I. Sameh ${ }^{d}$ \\ ${ }^{a}$ Geography \& Environment, University of Southampton, University Road, Southampton, SO17 1BJ, UK. \\ ${ }^{\mathrm{b}}$ Department of Geography, Reading Blue Coat School, Sonning Lane, Reading, RG4 6SU, UK. \\ ${ }^{c}$ Department of Geology, Cairo University, Gamaa Street, Giza, Cairo, Egypt. \\ ${ }^{\mathrm{d}}$ Egypt Nanotechnology Center (EGNC), Cairo University, Alexandria Desert Road, Sheikh Zayed, Egypt. \\ *Corresponding author: penningtonbt@gmail.com
}

\begin{abstract}
Elemental XRF analysis carried out on an $8 \mathrm{~m}$ long core from the Nile Delta reveals a gradual increase in the $\mathrm{Ca}$ /Ti ratio between $5000-4000 \mathrm{cal} \mathrm{BP}$ which is linked to the progressive development of hyper-aridity in this region. The increase results from elevated flux of aeolian material entering the Nile river system from calcareous source rock geologies in the dryer Egyptian Sahara. The most major increase in hyper-aridity occurs around $4000 \mathrm{cal} \mathrm{BP}$. Such a perspective suggests a locally abrupt, regionally time-transgressive inception of hyper-aridity in this region at the end of the African Humid Period. After this time, reorganisation of wind circulation meant that less Saharan-derived aeolian material entered the Nile Valley, and the contribution of aeolian material in the Nile's sedimentary signal was also dwarfed by an increase in Blue Nile sedimentary flux. Chronological control is provided by two radiocarbon dates and the top and bottom of a well-constrained pottery horizon that dates from the period of occupation of two nearby archaeological sites: Kom al-Ahmer and Kom Wasit.
\end{abstract}

Keywords: Egypt; Sahara; Desertification; African Humid Period; XRF; Kom al-Ahmer/Kom Wasit.

\section{Introduction}

In the early Holocene, the present Sahara desert hosted a savanna ecosystem with permanent lakes and characteristic Sahelian vegetation, under a climatic regime known as the "African Humid Period" (AHP) (DeMenocal et al., 2000; Gasse, 2000; Kuper and Kröpelin, 2006; Renssen et al., 2006;

Shanahan et al., 2015). The onset of the AHP was driven by gradually increasing northern hemisphere insolation and a concomitant northward movement of the ITCZ during the later Pleistocene (Williams et al., 2000; 2006; 2010; Williams, 2009). During the mid-Holocene, the reverse mechanism resulted in the gradual disappearance of this "green Sahara", and aridification of the area that has persisted until the present day. In the extreme north of the continent, aridification was also engendered by a decrease in Mediterranean winter rainfall over this same time period, a shift related to changes in the Arctic Oscillation (Rohling et al., 2002; Phillipps et al., 2012).

Many studies suggest a locally abrupt, but regionally gradual transition to a more arid climate between about $9000 \mathrm{cal} \mathrm{BP}$ and $5000 \mathrm{cal} \mathrm{BP}$, with the shift taking place at different times in different places (Kröpelin et al., 2008; Shanahan et al., 2015; Zielhofer et al., 2017), although the debate is not concluded, with other researchers suggesting a regionally abrupt change (DeMenocal et al., 2000; Egerer et al., 2016; Tierney et al., 2017; Zhao et al., 2017). In Egypt it appears to be the case that the shift to arid conditions may have taken place earlier in the north than the south (Kuper and Kröpelin, 2006; Wendorf et al., 2007), and the beginning of this episode of drying took place in a time- 
transgressive fashion $c .7000-5000$ cal BP. This time-frame, however, does not reflect the onset of hyper-aridity.

To reconstruct the times when different areas of the Egyptian Sahara became a hyper-arid desert (in which aeolian geomorphological processes dominated) some researchers have focussed on attempting to reconstruct population dynamics in the region through archaeological investigations. The results of these studies, however, paint a somewhat mixed picture. Investigations at Djara, in central-western Egypt, suggest onset of aridification around $7250 \mathrm{cal} \mathrm{BP}$, but total abandonment of the area $c .6500 \mathrm{cal}$ BP (Kindermann et al., 2006). Work around Nabta Playa in south-west Egypt suggest that the area may have become a hyper-arid desert after $c .4800 \mathrm{cal} \mathrm{BP}$, but with local rains returning $c .4350-3400$ cal BP (Wendorf et al., 2007; Schild and Wendorf, 2013). In the Gilf Kebir further west (and slightly to the north), hyper-aridity has been suggested to have started earlier, $c .5250 \mathrm{cal}$ BP. In northern Sudan, palaeoenvironmental data suggest that a variety of lake systems dried up around 5200-4200 cal BP (Ritchie et al., 1985; Hoelzmann et al., 2001; Clarke et al., 2016) and a major wadi system Wadi Howar - became extinct after $c .4200$ cal BP (Wendorf et al., 2007), but other data suggest settlements were abandoned due to aridity much earlier, c.6000 cal BP (Honegger and Williams, 2015). In the central Sahara, records from Lake Chad show the mobilisation of dust (and thus presumed hyper-aridity) beginning around 4300 cal BP (Kröpelin et al., 2008). Overall, however, when the studies are integrated it is generally thought that aridity may have reached a regional climax around $4200 \mathrm{cal}$ BP (Marshall et al., 2011; Blanchet et al., 2013).

Another way in which climatic change through this period in time can be investigated is by studying the alluvial history of the Nile, whose course traverses the whole of the Sahara in north-east Africa (Woodward et al., 2001; Macklin et al., 2015; Revel et al., 2015). Fluctuations in the main sources of sediment carried by this river can inform on the efficacy of erosional processes operating in different regions of eastern and north-eastern Africa, and - through this - climatic variability across the region. Much of the focus of hydroclimatic research in this region thus far has rightly been on understanding climatic changes in the headwaters of the Nile - a very important topic since it is precipitation in this region that controls the river flow (Krom et al., 2002; Revel et al., 2010; 2014; Hennekam et al., 2015; Macklin et al., 2015; Castañeda et al., 2016). However, it is also important to recognise that the history of aeolian sedimentary input (dust) into the Nile system can further inform on the pace and timing of the development of hyper-aridity in the Sahara, further north.

Therefore, in order to provide further information on the pace and nature of past environmental change in the eastern Sahara during the mid-Holocene, a core was collected in the north-west Nile Delta near the archaeological sites of Kom al-Ahmer/Kom Wasit from a well-understood sedimentary setting. It was then studied using X-ray fluorescence (XRF) analysis and dated using radiocarbon methods. XRF analysis can distinguish between the three main sedimentary inputs within northeast Africa: the Blue Nile/Atbara, the White Nile and the desert. The sediments originating from each of these areas have clear geochemical signatures, related to the source rock geologies (Fig. 1). The White Nile drains Archean crystalline basement rocks, and initially displays a geochemical signature enriched in Si and $\mathrm{Zr}$ but depleted in mobile alkai and alkaline earth metals (Garzanti et al., 2015, pp. $23,25)$, although downstream of the Sudd it displays a strongly depleted signature of recycled quartz. The Blue Nile \& Atbara, draining the complex geology of the Ethiopian highlands, instead carry sediments which are strongly enriched in $\mathrm{Ti}, \mathrm{Mn}, \mathrm{Fe}, \mathrm{Co}, \mathrm{Ni}, \mathrm{Cu}$ and $\mathrm{Ca}$ relative to the White Nile (Garzanti et al., 2015, p. 15). Sediment originating from the deserts - entering the Nile system either due to aeolian or wadi input - are enriched in carbonate and thus $\mathrm{Ca}$, and are also depleted in $\mathrm{Ti}$ (Krom et al., 1999; Schilman et al., 2001; Woronko, 2012; Garzanti et al., 2015), as can clearly be seen from the map of the distribution of calcareous rocks in the Nile basin (Fig. 1). Together, this means that sediments from the Blue Nile \& Atbara are enriched relative to those from the White Nile in $\mathrm{Ti}, \mathrm{Mn}, \mathrm{Fe}, \mathrm{Co}, \mathrm{Ni}, \mathrm{Cu}$ and $\mathrm{Ca}$, whilst sediments deriving from the desert are enriched relative to those from the main tributaries in $\mathrm{Ca}$, and depleted in $\mathrm{Ti}$.

The drying-out of the Sahara has important consequences for our understanding of cultural trajectories during this time period, and may have in part contributed to the emergence of the Ancient Egyptian 
state $c .5050$ cal BP (Brooks, 2006; Kuper and Kröpelin, 2006; Clarke et al., 2016). The collapse of the Old Kingdom c.4200 cal BP has also been linked in part to a decrease in Nile flood heights (Stanley et al., 2003).

\section{**FIGURES AT END**}

Fig. 1 Map of the Nile Basin and nearby areas, showing sub-catchments and location of calcareous geologies. After Woodward et al. (2015). Geological information compiled from a variety of sources (GMRD, 1981; Klitzsch et al., 1987; Tadesse et al., 2003; Tawadros, 2011; Fernandez-Alonso et al., 2012).

\section{Regional Setting}

The core analysed derives from geological investigations within the context of archaeological fieldwork around the predominantly Greco-Roman sites of Kom al-Ahmer and Kom Wasit in the north-western Nile Delta (Kenawi and Rossetti, 2013; Marchiori, 2014; Asolati et al., 2015; Mondin, 2016; Mondin et al., 2016) (Fig. 2). These sites have been under excavation since 2012, and geoarchaeological fieldwork in the vicinity has been ongoing since 2016 (Pennington, in press). Information from twenty-six boreholes has provided a perspective on the local palaeoenvironmental history of the area through time. This has been integrated with other work in the Nile Delta to be expressed within a regional framework (Pennington et al., 2017). The work comprised the first known geological and geoarchaeological research in this specific location, although palaeoenvironmental work has previously been carried out in the northern Nile Delta between Rosetta and Alexandria (Chen et al., 1992; Stanley et al., 1996; 2004), to the west and south (Wilson, 2007; Wilson and Grigoropoulos, 2009) and in the vicinity of Mahmudiya (Said, 1981, pp. 110-111).

\section{$\underline{2.1 \text { Broad geomorphological setting }}$}

The present landscape around Kom al-Ahmer and Kom Wasit is characterised by dense settlement and intensive cultivation of wheat, maize, rice and cotton, supported by a highly-regulated network of irrigation and drainage channels. The Rosetta branch of the Nile is located approximately $7 \mathrm{~km}$ to the east of the sites and this enters the Mediterranean some $23 \mathrm{~km}$ to the north. In prior periods, the delta geomorphology was very different. Although the coastline has occupied approximately the same position here since c. $5500 \mathrm{BC}$, a coastal lagoon to the north - Lake Edku - used to be significantly larger, and there were also a series of other lagoons further to the northwest and northeast. While these lagoons were probably never so large as to exist across the entire study area (Arbouille and Stanley, 1991; Chen et al., 1992) in the very recent past (1700-1800 AD) they may have extended southwards to a position near the sites, which were situated in an area of very marshy ground (Jacotin, 1828). The Rosetta/Bolbitine branch of the Nile seems to have existed only since the first millennium BC (Chen et al., 1992, pp. 550-551; Wilson and Gilbert, 2012, pp. 107-108); prior to this time the Canopic was the main distributary network in the western Delta, although its main course lay some distance further to the west (Stanley et al., 2004).

\subsection{Local palaeoenvironmental context}

Local landscape conditions in the northwestern Nile Delta were reconstructed from sediment samples taken from twenty-six cores in the vicinity. The results will be presented in detail in a forthcoming publication (Pennington, in press), but a summary of the geomorphology, palaeoenvironment and sedimentology of the area is summarised here for context.

At Kom al-Ahmer, archaeological and geoarchaeological work demonstrates that human activity in the landscape around the site may have begun as early as the Late Period, due to the discovery of ceramic artefacts. It was during the Ptolemaic Period though that accelerated settlement growth occurred, with the ancient settlement constructed upon levees of a former minor channel of the Nile to the west (Pennington, in press). During the Roman period, the settlement expanded westwards 
following the line of the riverbank, and the sedimentary sequence demonstrated both westward migration of the river channel, occasional flood events, development of a minor swampy backwater, and the eventual silting-up of the original river. Almost identical sedimentological sequences have also been found in other areas of the Nile Delta (Pennington and Thomas, 2016). The increasing expansion of the settlement, hydrological changes and dumping of occupation waste and cultural material into the former channel eventually led to the silting-up of the river in this location. The large amounts of Roman debris - including Late Roman pottery fragments - within these sediments constrain the channel's demise to the Late Roman period or later.

It is not known exactly from where this river originated. A number of ancient branches of the Nile's Canopic distributary existed some 8 to 16 kilometers further to the west (Stanley and Jorstad, 2006, p. 509), and so it is possible that this branch is another, more eastern, Canopic distributary. Some weight to this hypothesis is lent by recent geoarchaeological coring further south, which found a possible river channel to the northeast of Damanhur which was interpreted as part of the Canopic system (Wilson, 2007). On the other hand, the river could just as easily derive from the Rosetta/Bolbitine distributary network, which was coming into existence at this time period (Chen et al., 1992, pp. 550 551). A number of waterways linking the Rosetta branch with Lake Edku are known to have existed in this vicinity in more recent times (Stanley et al., 2004, p. 925; Cooper, 2014, pp. 60-62); this may have been an earlier such channel. Only a more regional programme of geoarchaeological research would be able to answer this question.

By Kom Wasit no major rivers contemporaneous with ancient occupation were detected to the south or southwest of the settlement, but it is possible that the river to the west of Kom al-Ahmer meandered around the northwestern margin of Kom Wasit. It was also clear that only the northern extent of Kom Wasit may have been constructed upon a river levee, and the southern area built upon the floodplain. The location of a section of the settlement within the floodplain explains the large quantities of ceramic artefacts identified at the base of the occupation levels, as this would have most probably been deliberately dumped in order to consolidate the waterlogged ground and provide a suitable building platform above an area of increased flood risk.

Despite the lack of conclusive evidence of a definitive former river channel by Kom Wasit, the sedimentological evidence did identify another ancient levee feature that suggests that there might have been a minor watercourse trending east to west between the two settlement sites. The fact that the maximum extent of this additional levee was identified at the same level as horizons containing the most evidence of human activity in the floodplain suggests that they are contemporaneous.

\section{$\underline{2.3 \text { Sedimentological context }}$}

The exact location of the core to be analysed was chosen within the context of this fieldwork for its distil setting, from a natural (non-archaeological) sedimentary context and far from known palaeochannels. The sediments retrieved are thought to have been deposited through distil alluvial deposition, and the facies represented characterise the bulk, overall landscape evolution of this part of the delta. Except for in the uppermost part of the core they are not thought to relate to the influence of local distributaries. The recovered sediments (Figs. 3,4) are thought to comprise four distinct units (Pennington, in press). No substantial unconformities are thought to exist within the sequence.

At the base are coarse silts to medium sands (Unit X). These have been interpreted as of ancient fluvial origin, and not aeolian, given the presence of mica (Pennington et al, in press). Similar deposits found from equivalent depths at Mahmudiya have also been interpreted as of fluvial origin (Said, 1981, pp.110-111). From 390cm to 680cm depth are a series of blue-black-grey (N 3/0) fine silts rich in organic matter (Unit G) which belong to the Bilqas 2 Member of the Bilqas Formation (Pennington et al., 2017). These are interpreted as representing a landscape dominated by extensive areas of swampy marshland and lakes, similar to that found in other locations nearby (Wunderlich, 1989; 1993). Above 390cm, Units H \& I make up the Bilqas 1 Member and comprise micaceous brown silts hosting rhizoconcretions and pottery, but with less organic matter. It is thought that these 
represent a more terrestrial landscape than previously, and this upwards transition from Unit $\mathrm{G}$ to Units $\mathrm{H} \& \mathrm{I}$ was driven by decreasing rates of relative sea-level rise and changing Nile discharge (Pennington et al. 2017).

\section{**FIGURES AT END**}

Fig. 2 Map showing the location of Kom al-Ahmer and Kom Wasit in their north-western delta context. The location of core AW26 is marked, and positions of ancient watercourses are indicated by arrows.

\section{Materials and methods}

Core AW26, located at 30.46043E, 31.17569N and at an elevation of approx. 0.5masl, was drilled to a depth of $775 \mathrm{~cm}$ using an Edelman-style (Eijkelkamp) hand auger and recorded in the field in terms of its basic geological characteristics (Pennington, in press). An approximate field estimate of grain size was provided through using a hand lens and grain-size comparator, or (for silt and clay grade material) by feeling it between the teeth. The core was then re-drilled, re-recorded and very carefully subsampled in the field at $5 \mathrm{~cm}$ intervals below a depth of $235 \mathrm{~cm}$, and at $10 \mathrm{~cm}$ intervals above this depth. XRF analysis was then carried out on the samples in Cairo University after study by the Markez al-Behouth using an Oxford Instruments X-MET 7500 portable XRF analyser (factorycalibrated) with a dwell time of 25.6s under a Mining LE FP setting. Analysis for carbon and water content was also carried out in Cairo University. Water content was determined by direct method according to ASTM D2216-10 by drying the sample at $110^{\circ} \mathrm{C}$ for $12 \mathrm{~h}$ and measuring the weight loss. Organic content was then determined by direct method according to ASTM D2974, by calculating the loss of weight after heating the dried sample in an oven at $550^{\circ} \mathrm{C}$ for 24 hours. The resulting elemental profiles were compared with the sedimentary information that was recorded in the field. The core was more coarsely subsampled above $235 \mathrm{~cm}$ due to the more sandy nature of the sediments and greater variability in grain-size above this depth, rendering any conclusions drawn from this part of the core more speculative. It was felt that the lower portion of the core provided a more reliable record than the upper.

In order to provide a chronology for the sedimentary deposition, both radiocarbon dates and archaeological considerations (pottery) were used. Two organic-rich samples were selected for radiocarbon dating, washed in distilled water and sieved to 300 microns before organic material suitable for dating was studied under a reflected light microscope, removed using tweezers and dated by 14 CHRONO (Table 1). To minimise contamination all laboratory equipment was cleaned using nitric acid before use; prior to radiocarbon dating samples were treated according to using standard laboratory procedures (Reimer et al., 2015). Radiocarbon ages have been calibrated to calendar dates BP using IntCal13 (Reimer et al., 2013).

Pottery was also used as a relative chronostratigraphic indicator (see acknowledgements), in a similar method as used elsewhere in Egypt (Bunbury et al., 2008; Pennington and Thomas, 2016; Toonen et al., 2018). The geoarchaeological fieldwork established the existence of a continuous sedimentary horizon containing numerous fragments of pottery ( $>1 \%$ by volume) and other cultural material (bone, slag, etc.) at a depth of approx. 170-350 cm below the subsurface in the hinterland of the archaeological sites of Kom al-Ahmer and Kom Wasit (Pennington, in press). Recovery of 64 identifiable fragments of pottery from this band and comparison with the corpus of material from the archaeological sites suggested that it dated from the same period as the sites: from the later Late Period (c.2550 cal BP) to Byzantine times $(c .1350 \mathrm{cal} \mathrm{BP})$, and represented sedimentary layers contemporaneous with occupation. In this particular core the layer was encountered at $170-320 \mathrm{~cm}$, and so in core AW26 is thought that sediments at a depth of $320 \mathrm{~cm}$ date to $c .2550 \mathrm{cal} \mathrm{BP}$, while sediments at $170 \mathrm{~cm}$ date to $c .1350 \mathrm{cal} \mathrm{BP}$. This pottery horizon was highly distinctive in the field (in almost every core drilled), and no pottery was present in any of the floodplain cores below this band, but of course it represents a more tentative dating estimate than the radiocarbon dates given that the ages estimated are not directly from the core sampled. 
An overall age-depth curve for core AW26 was constructed in Oxcal v.4.3 (Fig. 3). The assumed ages of the top and bottom of the pottery band were input with a 1-sigma error of 100 years, a level of uncertainty which was thought to be appropriate, while the top of the core was assumed to represent the year AD 1965, when the Aswan High Dam effectively caused sedimentation on the delta surface to cease. Deposition was modelled using a $\mathrm{P}_{\text {_ }}$ sequence with an initial value for $\mathrm{k}_{0}$ of 5.9 (assuming average sedimentation rates of approx. $1.7 \mathrm{~mm} / \mathrm{yr}$ in the western delta since $c .5000 \mathrm{cal} \mathrm{BP}$ ).

**FIGURES AT END**

Fig. 3 Depth-age determination and stratigraphy of core AW26.

Table 1: Details of radiocarbon dates and other material dated.

\begin{tabular}{ccccc}
\hline Lab code & $\begin{array}{c}\text { Depth } \\
(\mathrm{cm})\end{array}$ & Material & $\begin{array}{c}\text { Uncalibrated } \\
\text { RC date BP }\end{array}$ & $\begin{array}{c}\text { Calibrated age } \\
\text { BP }(2 \sigma)\end{array}$ \\
\hline UBA-35426 & $400-410$ & 6x seeds and a piece of wood charcoal & $3152 \pm 38$ & $3454-3253$ \\
UBA-35424 & $700-720$ & 6x pieces of monocot plant stem & $4280 \pm 40$ & $4967-4712$ \\
\hline
\end{tabular}

\section{Results}

Fig. 4 shows the results of the XRF analysis, and plots the recovered elemental profiles for $\mathrm{Ca}, \mathrm{Ti}, \mathrm{Rb}$, $\mathrm{K}, \mathrm{Mn}, \mathrm{Fe}, \mathrm{Sr}, \mathrm{Zr}$ and $\mathrm{S}$ against depth, as well as the elemental ratio $\mathrm{Ca} / \mathrm{Ti}$. Elemental profiles of other elements detected are shown in the Supplementary Information. Some of the variability within the records can be attributed to grain-size effects: $\mathrm{Ti}, \mathrm{Zr}$ and $\mathrm{Sr}$ appear to be concentrated in the coarser (coarse silt/very fine sand) portions of the sample, while Rb exists at a higher abundance in the finest silt and clay components. These trends are commonly seen in other alluvial sediments of comparable grade (Turner et al., 2015).

Some of the other records do not appear to correlate with grain-size, but suggest local environmental factors contributing to the variability. This can be inferred since some elements are clearly enriched in particular sedimentary units, which were defined a priori. Unit X, at the base, is geochemically distinct, with its upper boundary marked by a decrease in $\mathrm{K}, \mathrm{Ti}, \mathrm{Sr} \& \mathrm{Zr}$ and an increase in $\mathrm{Rb}$ and $\mathrm{Ca}$ (Fig. 4). Above this, Unit $\mathrm{G}$ is marked by elevated $\mathrm{Ca} \& \mathrm{Rb}$, depressed $\mathrm{Ti}, \mathrm{K}, \mathrm{Zr} \& \mathrm{Sr}$, and the occurrence of $\mathrm{S}$. The presence of $\mathrm{S}$ is clearly linked to the local precipitation of pyrite - a fact confirmed through optical microscopy. The upwards transition to Unit $\mathrm{H}$ is relatively gradual but is most clearly indicated by a decrease in $\mathrm{Ca} \& \mathrm{Rb}$, and increases in $\mathrm{Ti}, \mathrm{K} \& \mathrm{Sr}$, and shifts in related ratios. The uppermost unit, Unit I, is less geochemically distinct than the others.

On Fig. 5, the $\mathrm{Ca} / \mathrm{Ti}$ and $\mathrm{Sr} / \mathrm{Ti}$ records are re-expressed against time, calculated from the age-depth curve. The $\mathrm{Ca} / \mathrm{Ti}$ ratio is interpreted as reflecting the relative contributions of aeolian vs fluvial input, with increased $\mathrm{Ca}$ reflecting aeolian input from the desert. Ti is used to normalise the record as it is derived only from fluvial catchment weathering upstream. This figure shows a major increase in the $\mathrm{Ca} / \mathrm{Ti}$ ratio between 5000 and $3000 \mathrm{cal} \mathrm{BP}$.

Calcium is primarily interpreted as a proxy for input of desert sediment since the vast majority of calcareous rocks (and thus potential sources of $\mathrm{Ca}$ ) in the region are located in the western desert of Egypt (Fig. 1), mainly within the Eocene limestones of the Thebes and Mokkatam Groups, the Palaeocene Tarawan Group, and the Miocene Marmarica Formation (Klitzsch et al., 1987; Tawadros, 2011). Some calcium may also have been sourced from playa deposits in the desert (although this is unlikely given that most are dominated by Si rather than $\mathrm{Ca}$ (Embabi, 2017)). There are, however, a number of other possible source locations which could have led to the deposition of $\mathrm{Ca}$ and require discussion: the main Nile tributaries, authigenic precipitation, easterly sources, or remobilisation of calcium within the sediments. Calcium deposited in Nile Delta sediments of the delta is not through 
to predominantly derive from the main Nile tributaries system since a) there is not a great deal of limestone in these catchments; b) during the time period of elevated $\mathrm{Ca} / \mathrm{Ti}$ the relative sediment flux from these tributaries is thought to have been low (see section 5.1); and c) normalising the Ca record with Ti should mean that upstream inputs are not represented in the signal.

Neither is the calcium through to result from authigenic precipitation within the local environment, since $\mathrm{Sr}$ is depressed at these depths in the core. If the Ca record were reflective of local precipitation as $\mathrm{CaCO}_{3}$, it would be expected that $\mathrm{Sr}$ would also be deposited as $\mathrm{SrCO}_{3}$ (Martín-Puertas et al., 2011). The lack of elevated $\mathrm{Sr} / \mathrm{Ti}$ between 5000-3000 cal BP (Fig. 5) suggests that the Ca is allochthonous, deriving from the desert. In general, the calcium is presumed to manifest itself as disseminated dust fragments, given that large nodular calcium concretions were only observed in any quantity in a band around $2 \mathrm{~m}$ depth.

$\mathrm{Ca}$ is also not thought to result from vertical mobilisation by post burial pedogenesis. While the presence of occasional calcrete and rhizoconcretions point to minimal secondary carbonate deposition in sediments younger than $3 \mathrm{ka}$, (possibly as a result of redox conditions), previous elemental studies of Nile sediments have shown that typically Ca levels range from 1-4\% and have not been classified as a primary source element (Hamdan et al., 2018). In contrast, this paper has demonstrated that between 5-4 ka Ca levels reach 12\%, which support the conclusion of a non-Nile source of calcium carbonate. Although a small proportion of calcium carbonate may have dissolved out of the solid form, it is unlikely to have altered the resultant concentrations identified.

There is also of course a possibility that easterly winds could have transported calcium from limestones underlying the Arabian peninsula, Sinai and the Levant - a situation that probably occurs today, with the area experiencing some northeasterly wind directions during winter (Donner and Embabi, 2000). However, during the time period of highest Ca input (c. $4000 \mathrm{BP}$ ), the prevailing wind patterns were more westerly than at present, and so this situation is unlikely at that time (Brookes, 2003). The possibility could be fully discounted through further elemental studies in the eastern delta and elsewhere.

It cannot be said definitively whether the calcium came about as a result of increased wadi flux or from aeolian transport. However, it is thought to result from aeolian transport for a number of reasons. First, much of the limestone lies outside the Nile river catchment: the vast majority of major wadi systems entering the Nile only drain a small portion of the calcareous geologies of the western desert (Fig. 1); aeolian processes are therefore the only ones that could transport calcareous dust from the entire region of limestone geologies into the Nile Valley and river. Second, wadis are known not to have been particularly active during this time (5000-3000 cal BP), except for during very short periods (Pachur and Kröpelin, 1987; Welc and Marks, 2014; Woodward et al., 2015; Hamdan et al., 2018). Finally, increased calcium has been previously identified nearby as a strong marker of aeolian deposits (Woronko, 2012). Thus, the increase in the Ca/Ti record between 5000-3000 cal BP is thought to reflect an increase in the contribution of aeolian sediment from the desert.

\section{**FIGURES AT END** \\ Fig. 4 XRF and other data from core AW26. Division of the core into its constituent sedimentary units is also shown. The approximate grain-size is a field estimate - for key see Fig. 3; all other data are expressed in \% abundance. Arrows indicate the position of chronostratigraphic data-see Fig. 3. Geochemical data on this figure comprise $\mathrm{Ca}, \mathrm{Ti}, \mathrm{Rb}, \mathrm{K}, \mathrm{Mn}, \mathrm{Fe}, \mathrm{Sr}, \mathrm{Zr}$ and $\mathrm{S}$, as well as the calculated Ca/Ti ratio. Other elemental records are given in the Supplementary Information.}

**FIGURES AT END**

Fig. 5 Selected records plotted against time: a) Ca/Ti; b) independent data from an offshore Nile Delta core (Blanchet et al., 2013) representing the ratio of fluvial to aeolian input into the Nile system c) $\mathrm{Sr} / \mathrm{Ti}$. All vertical scales are dimensionless. 


\section{Discussion}

5.1 Gradual drying of Egyptian Sahara followed by reorganisation of wind circulation and increased $\underline{\text { Blue Nile sediment input }}$

The increase in $\mathrm{Ca} / \mathrm{Ti}$ between 5000-4000 cal BP, and subsequent decrease 4000-3000 cal BP (Fig. 5 ) is thought to reflect the progressive transformation of the Sahara into a hyper-arid regime dominated by aeolian processes, followed by a reorganisation of wind patterns in the region resulting in less windblown dust entering the Nile system, coupled with an increase in the sedimentary input of the Blue Nile. As more of the Sahara became an extreme desert, increasing amounts of calcareous dust - originating from the west - would have been transported by the predominantly westerly palaeowind patterns (Brookes, 2003) into the Nile Valley, finding its way into the river and delta sediments, and thus causing the increase in the $\mathrm{Ca} / \mathrm{Ti}$ ratio 5000-4000 cal BP. The most extensive episode of drying appears to have taken place towards the end of this period, around $4000 \mathrm{cal} \mathrm{BP}$.

Multi-proxy sedimentary provenance studies carried out in cores from the offshore Nile Delta (Blanchet et al., 2013; 2014) also support this, in that they highlight a particularly arid episode between 5000-3000 cal BP that culminated around 4300-3700 cal BP, characterised by a marked increase in aeolian dust input to Nile river sediments (Fig. 5). Other studies highlight a major increase in the Saharan aeolian contribution to Nile sediments starting 4000 cal BP (Box et al., 2011; Revel et al., 2015) - presumably recording the apex of this drying episode. Such a conclusion is also in agreement with another local study in the Egyptian Sahara nearby in the Faiyum oasis that looked at quartz grain roundness and found a major increase in aeolian transport c.4200-4000 cal BP (Zhao et al., 2017). It is also in broad agreement with the archaeological evidence from the western desert, described above.

However, because this XRF record integrates climatic changes through the Egyptian Nile, this Ca/Ti ratio can provide for a more spatially integrated outlook on the timing and pace of drying in the Egyptian Sahara than local studies. Because the area of calcareous geologies in the desert is wellknown (Fig. 1 - approximating the ancient political boundaries of Egypt as far south as the first cataract at Aswan), the increase in $\mathrm{Ca} / \mathrm{Ti}$ between 5000-4000 cal BP corresponds with the progressive drying-out of this region as a whole. As such, given that the $\mathrm{Ca} / \mathrm{Ti}$ increase occurs over a $c .1000$ yearlong period, it is proposed here that the transition to a hyper-arid desert in Egypt took place in a spatially progressive fashion through the third millennium BC, presumably earliest in the north, and later in the south (Shanahan et al., 2015). Such a perspective of course allows for observations of locally abrupt aridification. In further support of such a conclusion, it is interesting that aeolian sedimentary input to the Nile is not noted at this time (5000-3000 cal BP) further to the south in north/central Sudan (Woodward et al., 2015), where it increases only from c.3000 cal BP. Such an observation makes complete sense if a time-transgressive drying hypothesis from north to south is accepted: prior to $c .3000$ cal BP Egypt would have been hyper-arid, but not yet north/central Sudan.

The subsequent decrease in $\mathrm{Ca} / \mathrm{Ti}$ between 4000 and $3000 \mathrm{cal} \mathrm{BP}$ is not thought to reflect decreasing aridity of the Sahara, for which there is little evidence, but instead a combination of reorganisation of wind circulation in the region as well as increasing Blue Nile sediment flux swamping the aeolian signal. Prior to this time, the predominant wind direction was westerly (Brookes, 2003), and these winds could easily transport dust originating from the calcareous geologies of the western desert into the Nile Valley (Fig. 1). After 3000-4000 cal yr BP, however, the prevailing wind direction shifted to northerly (Brookes, 2003), a pattern which persists to this day. Northerly winds would not transport as much calcareous dust into the Nile Valley as the previous westerly winds, and so the decrease in $\mathrm{Ca} / \mathrm{Ti}$ can be seen as reflecting this gradual reorganisation of wind direction. If the wind direction had not changed, it is thought that the amount of aeolian dust entering the Nile river (and reflected in the $\mathrm{Ca} / \mathrm{Ti}$ ratio) would remain elevated to the present day. The decrease in $\mathrm{Ca} / \mathrm{Ti}$ is also likely partially a result of increasing Blue Nile sedimentary input through this time period (section 5.2), a signal which would swamp the aeolian contribution (Blanchet et al., 2014; Hamdan et al., 2018). Very similar conclusions were arrived at by Schilman et al. (2001), who found Saharan dust to comprise 65\% of 
offshore sediments at 4000 cal BP, but an increase in Blue Nile sediment flux thereafter meant that more modern deposits predominantly displayed a signature of the Ethiopian Highlands.

\section{$\underline{5.2 \text { Increase in Blue Nile sediment flux from c.3600 cal BP }}$}

The XRF data appear to suggest increasing Blue Nile sedimentary flux since approx. 3600 cal BP (upwards of $4.5 \mathrm{~m}$ depth) Increasing Ti seems to suggest increasing Blue Nile deposits from the Ethiopian Highlands (section 1), while at the same time K also increases, which may be similarly linked with increasing smectite deriving from the Blue Nile (Hamdan et al., 2018). Such a record matches well with other suggestions of increasing Blue Nile sediment flux from $c .4000 \mathrm{cal}$ BP as a result of increasing aridity in the Ethiopian Highlands and correspondingly increased weathering and sediment flux (Krom et al., 1999; Schilman et al., 2001; Box et al., 2011), and is lent further credence by the fact that $\mathrm{Rb}$ - a potential proxy for chemical weathering upstream (Burnett et al., 2011) decreases sympathetically at the same time (Fig. 4). Other elements that could potentially also inform on the relative sedimentary fluxes of the Blue and White Nile tributaries are $\mathrm{Co}, \mathrm{Ni}$ and $\mathrm{Cu}$ (Garzanti et al., 2015), but these were unfortunately detected only very sporadically (see SI), and cannot be reliably used to suggest changes in sedimentary provenance. Stable Mn and Fe probably relate to the redox state of the local environment and not upstream variability in the White Nile / Blue Nile sediment ratio.

\subsection{The 4200 year event?}

Interestingly, around $4200 \mathrm{cal} \mathrm{BP}(5.8 \mathrm{~m}$ depth) there is a great deal of variability in the $\mathrm{Ca} / \mathrm{Ti}$ ratio and other elemental abundances in the sediments (Figs. 4, 5). This time period is known to be one of climatic change, with a variety of indicators suggesting low Nile floods (Bell, 1970; 1971; Butzer, 1976; Said, 1993; Stanley et al., 2003), and possibly episodic rainfall events (Welc and Marks, 2014), both of which may have contributed in some way to the decline of the Old Kingdom in Egypt (Stanley et al., 2003; Butzer, 2012).

Although no definitive conclusions can be drawn from the data recorded, the period certainly seems one of intense change. In particular, the sedimentary XRF data - especially the $\mathrm{Ti}, \mathrm{Sr}$ and $\mathrm{Zr}$ records reflect a slight increase in deposited grain-size around $4200 \mathrm{cal} \mathrm{BP}$. While this observation of course may result from local environmental factors it is tempting to suggest that the increase may alternatively have been driven from a number of episodes of higher flow resulting from increased rainfall activating local wadi systems (Welc and Marks, 2014). Such events would have come within the general pattern of low floods at this time.

Subsequently, during the First Intermediate Period (c.4130-4055 cal BP), it seems that aeolian influx into the Nile Valley was at its greatest, as can be seen by the peak in the $\mathrm{Ca} / \mathrm{Ti}$ ratio. This agrees with other observations of sand invasion at this time (Butzer, 1959; Bell, 1971; Welc and Marks, 2014).

\subsection{Nile Delta aggradation rates and local environmental history}

As well as informing on regional patterns of climate change across north-east Africa, the chronostratigraphic and XRF data collected can inform further on the aggradation and more local environmental history of this portion of the Nile Delta. The aggradation history of the Holocene Nile Delta is quite poorly-understood, being constructed from only 71 pieces of age-depth information (Pennington et al., 2017). The four dates in this core (Table 1) increase the database for the fluvial region of the Nile Delta by some 6\%, and will be useful in future reconstructions. Age-depth information for this time period in the north-west delta is particularly sparse. This core shows slightly faster aggradation than some other cores in the region (Pennington et al., 2017), and a slowing-down of aggradation rates around the second millennium BC, perhaps linked with a change in the local environment. 
The variability within the XRF data also support most of the original stratigraphic divisions of the hinterland geology (Units X, G, H \& I - see section 4), suggesting that earlier conclusions were correct to divide the sediments as such. Previous work interpreted Unit G as comprising swampy semi-lacustrine environments, and Units H \& I as better-drained floodplain environments (Pennington, in press). Such an identification is supported by the fact that $\mathrm{S}$ is encountered within Unit $\mathrm{G}$ within pyrite. Pyrite is deposited only under highly reducing conditions and thus supports the interpretation of Unit $\mathrm{G}$ as comprising landscapes hosting very large amounts of decomposing organic material.

However, Unit X was previously interpreted as representing ancient fluvial deposition of the Minuf Member of the Mit Ghamr Formation. The radiocarbon date of 4967-4712 cal BP within the top of Unit X instead suggests that this unit (of which only the very top was ever penetrated) is not the Minuf Member but is instead more likely another part of the Bilqas 2 Member; the increased grain size being simply due to variability within the unit.

\section{Conclusions}

Overall, the results of this XRF analysis suggest that during the period 5000-4000 cal BP, the Egyptian Sahara progressively became a hyper-arid desert in which aeolian geomorphological processes dominated. This transition may have been locally abrupt but regionally latitudinally timetransgressive, perhaps with northern areas becoming dryer before southern areas. By c.4000 cal BP, however, the whole of the Egyptian Sahara was a desert. After this time, XRF analysis of Nile Delta sediments cannot as easily inform on the nature of climatic change within the Sahara desert because a reorganisation of wind patterns in the region reduced the flux of material deriving from the desert entering the Nile; the aeolian signal was also dwarfed by an increase in Blue Nile sedimentary flux. This data and approach to informing on the development of hyper-aridity in the Sahara complements other approaches variously relying on vegetation modelling, geomorphological arguments, or offshore proxy data, in providing a holistic approach on the progressive desertification of northern Africa.

The increasing desertification through the fourth millennium in Egypt may have exacerbated environmental pressures associated with low Nile flow - and perhaps also local rainstorms (Welc and Marks, 2014) - at the end of the Old Kingdom c.4200 cal BP. Prior to this time, people were obviously taking some resources from the desert, as suggested, for example by tomb scenes dating to the fifth dynasty (c.2500-2350BC) which show hunting scenes in a savanna-type landscape (Butzer, 1976). Once the Egyptian Sahara had become fully arid, such activities would have been no longer possible and this may have caused extra stress on populations in the Nile Valley, contributing in some way to social change at this juncture in Ancient Egyptian history.

\section{Acknowledgements}

The fieldwork was carried out as part of the Kom al-Ahmer/Kom Wasit Archaeological Project, an archaeological investigation run by Padua University and the Centro Archeologico Italo-Egiziano (CAIE) in collaboration with the Ministry of State for Antiquities in Egypt (MSA). Great thanks are therefore due to the directors of this project: Cristina Mondin, Michele Asolati, Giorgia Marchiori, and Mohamed Kenawi. Identification and dating of the pottery fragments was undertaken by Dr Mohamed Kenawi. The authors also gratefully acknowledge Mohamed Abdalla of the MSA, the farmers of Kom al-Ahmer and Kom Wasit for their hospitality, and Ahmed Katr, Islam Sayeed, Mustafa Jumma and Alaa Mimi for their work in the core drilling.

Funding: The fieldwork was funded through the Kom al-Ahmer/Kom Wasit Archaeological Project, Padua University, Ministry of Italian Foreign Affairs, and the CAIE. The subsequent analysis was supported by the Royal Geographical Society with IBG (Postgraduate Research Award) and the Quaternary Research Association (New Research Workers Award). 


\section{Data availability}

Datasets related to this article are hosted at Mendeley Data.

Supplementary data is also provided within the submission.

\section{References}

Arbouille, D., Stanley, D.J., 1991. Late Quaternary evolution of the Burullus lagoon region, northcentral Nile Delta, Egypt. Marine Geology 99, 45-66.

Asolati, M., Kenawi, M., Marchiori, G., Mondin, C., 2015. Alla Ricerca della Capitale Perduta, Kom al-Ahmer e Kom Wasit. Archeologia Viva 171, 18-27.

Bell, B., 1970. The oldest records of the Nile Floods. The Geographical Journal 136, 569-573.

Bell, B., 1971. The dark ages in ancient history: the first dark age in Egypt. American Journal of Archaeology 1-26.

Blanchet, C.L., Tjallingii, R., Frank, M., Lorenzen, J., Reitz, A., Brown, K., Feseker, T., Brückmann, W., 2013. High and low-latitude forcing of the Nile river regime during the Holocene inferred from laminated sediments of the Nile deep-sea fan. Earth and Planetary Science Letters 364, 98110.

Blanchet, C.L., Frank, M., Schouten, S., 2014. Asynchronous changes in vegetation, runoff and erosion in the Nile river watershed during the Holocene. PLOS One 9, 1-18.

Box, M.R., Krom, M.D., Cliff, R.A., Bar-Matthews, M., Almogi-Labin, A., Ayalon, A., Paterne, M., 2011. Response of the Nile and its catchment to millennial-scale climatic change since the LGM from $\mathrm{Sr}$ isotopes and major elements of East Mediterranean sediments. Quaternary Science Reviews 30, 431-442.

Brookes, I.A., 2003. Geomorphic indicators of Holocene winds in Egypt's Western Desert. Geomorphology 56, 155-166.

Brooks, N., 2006. Cultural responses to aridity in the middle Holocene and increased social complexity. Quaternary International 151, 29-46.

Bunbury, J.M., Graham, A., Hunter, M.A., 2008. Stratigraphic landscape analysis: charting the Holocene movements of the Nile at Karnak through ancient Egyptian time. Geoarchaeology 23, 351-373.

Burnett, A.P., Soreghan, M.J., Scholz, C.A., Brown, E.T., 2011. Tropical East African climate change and its relation to global climate: A record from Lake Tanganyika, Tropical East Africa, over the past 90+ kyr. Palaeogeography, Palaeoclimatology, Palaeoecology 303, 155-167.

Butzer, K.W., 1959. Some recent geological deposits in the Egyptian Nile valley. The Geographical Journal 125, 75-79.

Butzer, K.W., 1976. Early Hydraulic Civilization in Egypt. University of Chicago Press, Chicago.

Butzer, K.W., 2012. Collapse, environment, and society. PNAS 109, 3632-3639.

Castañeda, I.S., Schouten, S., Pätzold, J., Lucassen, F., Kasemann, S., Kuhlmann, H., Schefuß, E., 2016. Hydroclimate variability in the Nile River basin during the past 28,000 years. Earth and Planetary Science Letters 438, 47-56.

Chen, Z., Warne, A.G., Stanley, D.J., 1992. Late Quaternary evolution of the northwest Nile Delta between Rosetta and Alexandria, Egypt. Journal of Coastal Research 8, 527-561.

Clarke, J., Brooks, N., Banning, E.B., Bar-Matthews, M., Campbell, S., Clare, L., Cremaschi, M., 
Lernia, S. di, Drake, N., Gallinaro, M., Manning, S., Nicoll, K., Philipm, G., Rosen, S., Schoop, U.-D., Tafuri, M.A., Weninger, B., Zerbonig, A., 2016. Climatic changes and social transformations in the Near East and North Africa during the 'long' 4th millennium BC: a comparative study of environmental and archaeological evidence. Quaternary Science Reviews 136, 96-121.

Cooper, J.P., 2014. The Medieval Nile: Route, navigation, and landscape in Islamic Egypt. The American University in Cairo Press, Cairo.

DeMenocal, P., Ortiz, J., Guilderson, T., Adkins, J., Sarnthein, M., Baker, L., Yarusinsky, M., 2000. Abrupt onset and termination of the African Humid Period: rapid climate responses to gradual insolation forcing. Quaternary Science Reviews 19, 347-361.

Donner, J., Embabi, N.S., 2000. The significance of yardangs and ventifacted rock outcrops in the reconstruction of changes in the Late Quaternary wind regime in the Western Desert of Egypt. Quaternaire 11, 179-185.

Egerer, S., Claussen, M., Reick, C., Stanelle, T., 2016. Could gradual changes in Holocene Saharan landscape have caused the observed abrupt shift in North Atlantic dust deposition? Earth and Planetary Science Letters 473, 104-112.

Embabi, N.S., 2017. Landscapes and Landforms of Egypt: Landforms and Evolution. Springer, World Geomorphological Landscapes.

Fernandez-Alonso, M., Cutten, H., Waele, B. de, Tack, L., Tahon, A., Baudet, D., Barritt, S.D., 2012. The Mesoproterozoic Karagwe-Ankole Belt (formerly the NE Kibara Belt): the result of prolonged extensional intracratonic basin development punctuated by two short-lived far-field compressional events. Precambrian Research 216-219, 63-86.

Garzanti, E., Andò, S., Padoan, M., Vezzoli, G., El-Kammar, A., 2015. The modern Nile sediment system: processes and products. Quaternary Science Reviews 130, 9-56.

Gasse, F., 2000. Hydrological changes in the African tropics since the Last Glacial Maximum. Quaternary Science Reviews 19, 189-211.

GMRD, 1981. Geological Map of the Sudan. Ministry of Energy \& Mines, Geological \& Mineral Resources Department, Khartoum.

Hamdan, M.A., Hassan, F.A., Flower, R.J., Leroy, S.A.G., Shallaly, N.A., Flynne, A., 2018. Source of Nile sediments in the floodplain at Saqqara inferred from mineralogical, geochemical, and pollen data, and their palaeoclimatic and geoarchaeological significance. Quaternary International.

Hennekam, R., Donders, Timme, H., Zwiep, K., Lange, G.J. de, 2015. Integral view of Holocene precipitation and vegetation changes in the Nile catchment area as inferred from its delta sediments. Quaternary Science Reviews 130, 189-199.

Hoelzmann, P., Keding, B., Berke, H., Kröpelin, S., Kruze, H.J., 2001. Environmental change and archaeology: lake evolution and human occupation in the Eastern Sahara during the Holocene. Palaeogeography, Palaeoclimatology, Palaeoecology 169, 193-217.

Honegger, M., Williams, M.A.J., 2015. Human occupations and environmental changes in the Nile Valley during the Holocene: The case of Kerma in Upper Nubia (northern Sudan). Quaternary Science Reviews 130, 141-154.

Jacotin, M., 1828. Description de l'Égypte: ou recueil des observations et des recherches qui ont été faites en Égypte pendant l'expédition de l'armée française (Vol. 6): Carte topographique de L’Égypte. Description de l'Égypte, Book 6, Paris.

Kenawi, M., Rossetti, I., 2013. Kom Al-Ahmer I (Antica Metelis?) Rapporto Preliminare sulle 
Missioni 2008--2012. In: Pirelli, R. (Ed.), R.I.S.E. VI: Ricerche Italiane e Scavi in Egitto. Istituto Italiano di Cultura Centro Archeologico Italiano, Cairo.

Kindermann, K., Bubenzer, O., Nussbaum, S., Riemer, H., Darius, F., Pöllath, N., Smettan, U., 2006. Palaeoenvironment and Holocene land use of Djara, Western Desert of Egypt. Quaternary Science Reviews 25, 1619-1637.

Klitzsch, E., List, F.K., Pöhlmann, G., 1987. Geological Map of Egypt 1:500 000. Conoco Coral, Egyptian General Petroleum Corporation, Institut für Angewandte Geodäsie, Technische Fachhochschule Berlin, Cairo.

Krom, M.D., Cliff, R.A., Eijsink, L.M., Herut, B., Chester, R., 1999. The characterisation of Saharan dusts and Nile particulate matter in surface sediments from the Levantine basin using $\mathrm{Sr}$ isotopes. Marine Geology 155, 319-330.

Krom, M.D., Stanley, D.J., Cliff, R.A., Woodward, J.C., 2002. Nile River sediment fluctuations over the past $7000 \mathrm{yr}$ and their key role in sapropel development. Geology 30, 71-74.

Kröpelin, S., Verschuren, D., Lézine, A.M., Eggermont, H., Cocquyt, C., Francus, P., Cazet, J.P., Fagot, M., Rumes, B., Russell, J.M., Darius, F., Conley, D.J., Schuster, M., Suchodeletz, H. von, Engstrom, D.R., 2008. Climate-driven ecosystem succession in the Sahara: the past 6000 years. Science 320, 765-768.

Kuper, R., Kröpelin, S., 2006. Climate-controlled Holocene occupation in the Sahara: motor of Africa's evolution. Science 313, 803-807.

Macklin, M.G., Toonen, W.H.J., Woodward, J.C., Williams, M.A.J., Flaux, C., Marriner, N., Nicoll, K., Verstraeten, G., Spencer, N., Welsby, D., 2015. A new model of river dynamics, hydroclimatic change and human settlement in the Nile Valley derived from meta-analysis of the Holocene fluvial archive. Quaternary Science Reviews 130, 109-123.

Marchiori, G., 2014. Decline, migration and revival: Kom al-Ahmer and Kom Wasit, a history of a forgotten city. In: Platts, H., Pearce, J., Barron, C., Lundock, J., Yoo, J. (Eds.), TRAC 2013, Proceedings of the Twenty-Third Annual Theoretical Roman Archaeology Conference. Oxbow Books, Oxford, pp. 79-89.

Marshall, M.H., Lamb, H.F., Huws, D., Davies, S.J., Bates, R., Bloemendal, J., Boyle, J., Leng, M.J., Umer, M., Bryant, C., 2011. Late Pleistocene and Holocene drought events at Lake Tana, the source of the Blue Nile. Global and Planetary Change 78, 147-161.

Mondin, C., 2016. Late Roman imported red slip ware in the Metelis region (Alexandria, Egypt). Libyan Studies 47, 129-147.

Mondin, C., Asolati, M., Rosa, N. La, Marchiori, G., Kenawi, M., 2016. Kom al Ahmer-Kom Wasit Archaeological Project: i primi resulti della campagna di scavo 2016. Studi di egittologia e papirologia 13, 65-74.

Pachur, H.J., Kröpelin, S., 1987. Wadi Howar: paleoclimatic evidence from an extinct river system in the southeastern Sahara. Science 237, 298-300.

Pennington, B.T., n.d. Palaeoenvironments of the northwest Nile Delta: the ancient landscape context of Kom al-Ahmer/Kom Wasit. In: Kenawi, M. (Ed.), Kom Al-Ahmer/Kom Wasit I. Archaeopress, Oxford.

Pennington, B.T., Thomas, R.I., 2016. Paleoenvironmental surveys at Naukratis and the Canopic branch of the Nile. Journal of Archaeological Science: Reports 7, 180-188. doi:10.1016/j.jasrep.2016.03.053

Pennington, B.T., Sturt, F., Wilson, P., Rowland, J., Brown, A.G., 2017. The fluvial evolution of the Holocene Nile Delta. Quaternary Science Reviews 170, 212-231. 
Phillipps, R., Holdaway, S., Wendrich, W., Cappers, R., 2012. Mid-Holocene occupation of Egypt and global climatic change. Quaternary International 251, 64-76.

Reimer, P.J., Bard, E., Bayliss, A., Beck, J.W., Blackwell, P.G., Ramsey, C.B., Buck, C.E., Cheng, H., Lawrence, R.E., Friedrich, M., Grootes, P.M., Guilderson, T.P., Haflidason, H., Hajdas, I., Hatté, C., Heaton, T.J., Hoffmann, D.L., Hogg, A.G., Hughen, K.A., Kaiser, K.F., Kromer, B., Manning, S.W., Niu, M., Reimer, R.W., Richards, D.A., Scott, E.M., Southon, J.R., Staff, R.A., Turney, C.S.M., Plicht, J. van der, 2013. IntCal13 and Marine13 Radiocarbon Age Calibration Curves 0--50,000 Years cal BP. Radiocarbon 55, 1869-1887.

Reimer, P.J., Hoper, S., McDonald, J., Reimer, R., Svyatko, S., Thompson, M., 2015. Laboratory protocols used for AMS radiocarbon dating at the 14CHRONO centre. English Heritage, Belfast.

Renssen, H., Brovkin, V., Fichefet, T., Goosse, H., 2006. Simulation of the Holocene climate evolution in northern Africa: the termination of the African Humid Period. Quaternary International 150, 95-102.

Revel, M., Ducassou, E., Grousset, F.E., Bernasconi, S.M., Migeon, S., Revillon, S., Mascle, J., Murat, A., Zaragosi, S., Bosch, D., 2010. 10,000 years of African monsoon variability recorded in sediments of the Nile margin. Quaternary Science Reviews 29, 1342-1362.

Revel, M., Colin, C., Bernasconi, S., Combourieu-Nebout, N., Ducassou, E., Grousset, F.E., Rolland, Y., Migeon, S., Bosch, D., Brunet, P., Zhao, Y., Mascle, J., 2014. 21,000 years of Ethiopian African monsoon variability recorded in sediments of the western Nile deep-sea fan. Regional Environmental Change 14, 1685-1696.

Revel, M., Ducassou, E., Skonieczny, C., Colin, C., Bastian, L., Bosch, D., Migeon, S., Mascle, J., 2015. 20,000 years of Nile River dynamics and environmental changes in the Nile catchment area as inferred from Nile upper continental slope sediments. Quaternary Science Reviews 130, 200-221.

Ritchie, J.C., Eyles, C.H., Haynes, C. V, 1985. Sediment and pollen evidence for a middle Holocene humid period in the Eastern Sahara. Nature 314, 352-355.

Rohling, E.J., Casford, J., Abu-Zied, R., Cooke, S., Mercone, D., Thomson, J., Croudace, I., Jorissen, F.J., Brinkhuis, H., Kallmeyer, J., Wefer, G., 2002. Rapid Holocene climate changes in the Eastern Mediterranean. In: Hassan, F.A. (Ed.), Droughts, Food and Culture: Ecological Change and Food Security in Africa's Later Prehistory. Kluwer Academic Publishers, New York, pp. $35-46$.

Said, R., 1981. The Geological Evolution of the River Nile. Springer-Verlag, New York.

Said, R., 1993. The Nile River: Geology, hydrology and utilization. Pergamon Press, New York.

Schild, R., Wendorf, F., 2013. Early and middle Holocene paleoclimates in the south western desert of Egypt - the world before unification. Studia Quaternaria 30, 125-133.

Schilman, B., Bar-Matthews, M., Almogi-Labin, A., Luz, B., 2001. Global climate instability reflected by Eastern Mediterranean marine records during the late Holocene. Palaeogeography, Palaeoclimatology, Palaeoecology 176, 157-176.

Shanahan, T.M., McKay, N.P., Hughen, K.A., Overpeck, J.T., Otto-Bliesner, B., Heil, C.W., King, J., Scholz, C.A., Peck, J., 2015. The time-transgressive termination of the African Humid Period. Nature Geoscience 8, 140-144.

Stanley, D.J., Jorstad, T.F., 2006. Buried Canopic channel identified near Egypt's Nile delta coast with radar (SRTM) imagery. Geoarchaeology 21, 503-514.

Stanley, D.J., Mcrea Jr, J.E., Waldron, J.C., 1996. Nile Delta Drill Core and Sample Database for 
1985-1994: Mediterranean Basin (MEDIBA) program. Smithsonian Institution Press, Washington, D.C.

Stanley, D.J., Krom, M.D., Cliff, R.A., Woodward, J.C., 2003. Nile flow failure at the end of the Old Kingdom, Egypt: strontium isotope and petrologic evidence. Geoarchaeology 18, 395-402.

Stanley, D.J., Warne, A.G., Schnepp, G., 2004. Geoarchaeological interpretation of the Canopic, largest of the relict Nile Delta distributaries, Egypt. Journal of Coastal Research 20, 920-930.

Tadesse, S., Milesi, J.-P., Deschamps, Y., 2003. Geology and mineral potential of Ethiopia: a note on geology and mineral map of Ethiopia. Journal of African Earth Sciences 36, 273-313.

Tawadros, E., 2011. Geology of North Africa. CRC Press, Boca Raton.

Tierney, J.E., Pausata, F.S.R., DeMenocal, P.B., 2017. Rainfall regimes of the Green Sahara. Science Advances 3, 1-9.

Toonen, W.H.J., Graham, A., Pennington, B.T., Hunter, M.A., Strutt, K.D., Barker, D.S., MassonBerghoff, A., Emery, V.L., In Press, 2018. Holocene fluvial history of the Nile floodplain at ancient Thebes (Luxor, Egypt) and its relation with cultural dynamics and basin-wide hydroclimatic variability. Geoarchaeology 33, 273-290.

Turner, J.N., Jones, A.F., Brewer, P.A., Macklin, M.G., Rassner, S.M., 2015. Micro-XRF applications in fluvial sedimentary environments of Britain and Ireland: progress and prospects. In: Croudace, I.W., Guy Rothwell, R. (Eds.), Micro-XRF Studies of Sediment Cores: Applications of a Non-Destructive Tool for the Environmental Sciences. Springer, Dordrecht, pp. 227-266.

Welc, F., Marks, L., 2014. Climate change at the end of the Old Kingdom in Egypt around 4200 BP: new geoarchaeological evidence. Quaternary International 324, 124-133.

Wendorf, F., Karlén, W., Schild, R., 2007. Middle Holocene environments of north and east Africa, with special emphasis on the African Sahara. In: Anderson, D.G., Maasch, K.A., Sandweiss, D.H. (Eds.), Climate Change and Cultural Dynamics: A Global Perspective on Mid-Holocene Transitions. Elsevier, Amsterdam, pp. 189-227.

Williams, M.A.J., 2009. Late Pleistocene and Holocene environments in the Nile basin. Global and Planetary Change 69, 1-15.

Williams, M.A.J., Adamson, D., Cock, B., McEvedy, R., 2000. Late Quaternary environments in the White Nile region, Sudan. Global and Planetary Change 26, 305-316.

Williams, M.A.J., Talbot, M., Aharon, P., Salaam, Y.A., Williams, F., Bredeland, K.I., 2006. Abrupt return of the summer monsoon 15,000 years ago: new supporting evidence from the lower White Nile Valley and Lake Albert. Quaternary Science Reviews 25, 2651-2665.

Williams, M.A.J., Williams, F.M., Duller, G.A.T., Munro, R.N., El-Tom, O.A.M., Barrows, T.T., Macklin, M., Woodward, J., Talbot, M., Haberlah, D., Fluin, J., 2010. Late Quaternary floods and droughts in the Nile Valley, Sudan: new evidence from optically stimulated luminescence and AMS radiocarbon dating. Quaternary Science Reviews 29, 1116-1137.

Wilson, P., 2007. The Western Delta Regional Survey. https://community.dur.ac.uk/penelope.wilson/Delta/Survey.html (last accessed February 2017).

Wilson, P., Gilbert, G., 2012. Prehistoric Sais: Results from the Western Delta Floodplain. In: Kabacinski, J., Chłodnicki, M, M., Kobusiewicz, M. (Eds.), Prehistory of Northeastern Africa: New Ideas and Discoveries. Poznań Archaeological Museum, Poznań, pp. 25-40.

Wilson, P., Grigoropoulos, D., 2009. The West Nile Delta Regional Survey, Beheira and Kafr elSheikh provinces. Egypt Exploration Society, London.

Woodward, J., Macklin, M., Fielding, L., Miller, I., Spencer, N., Welsby, D., Williams, M.A.J., 2015. 
Shifting sediment sources in the world's longest river: a strontium isotope record for the Holocene Nile. Quaternary Science Reviews 130, 124-140.

Woodward, J.C., Welsby, D., Macklin, M.G., 2001. The Holocene fluvial sedimentary record and alluvial geoarchaeology in the Nile Valley of northern Sudan. In: Woodward, J.C., Maddy, D., Macklin, M.G. (Eds.), River Basin Sediment Systems: Archives of Environmental Change. A. A. Balkema, Lisse, pp. 327-355.

Woronko, B., 2012. Late-Holocene dust accumulation within the ancient town of Marea (coastal zone of the South Mediterranean Sea, N Egypt). Quaternary International 266, 4-13.

Wunderlich, J., 1989. Untersuchungen zur Entwicklung des westlichen Nildeltas im Holozän. Philipps-Universität Marburg.

Wunderlich, J., 1993. The natural conditions for Pre-and Early Dynastic settlement in the western Nile Delta around Tell el-Fara'in, Buto. In: Krzyzaniak, L., Kobusiewicz, M., Alexander, J. (Eds.), Environmental Change and Human Culture in the Nile Basin and Northern Africa until the 2nd Millennium B.C. Poznań Archaeological Museum, Poznań, pp. 259-266.

Zhao, X., Liu, Y., Salem, A., Marks, L., Welc, F., Sun, Q., Jiang, J., Chen, J., Chen, Z., 2017. Migration of the Intertropical Convergence Zone in North Africa during the Holocene: Evidence from variations in quartz grain roundness in the lower Nile valley, Egypt. Quaternary International 449, 22-28.

Zielhofer, C., Suchodoletz, H. von, Fletcher, W.J., Schneider, B., Dietze, E., Schlegel, M., Schepanski, K., Weninger, B., Mischke, S., Mikdad, A., 2017. Millennial-scale fluctuations in Saharan dust supply across the decline of the African Humid Period. Quaternary Science Reviews 171, 119-135. 



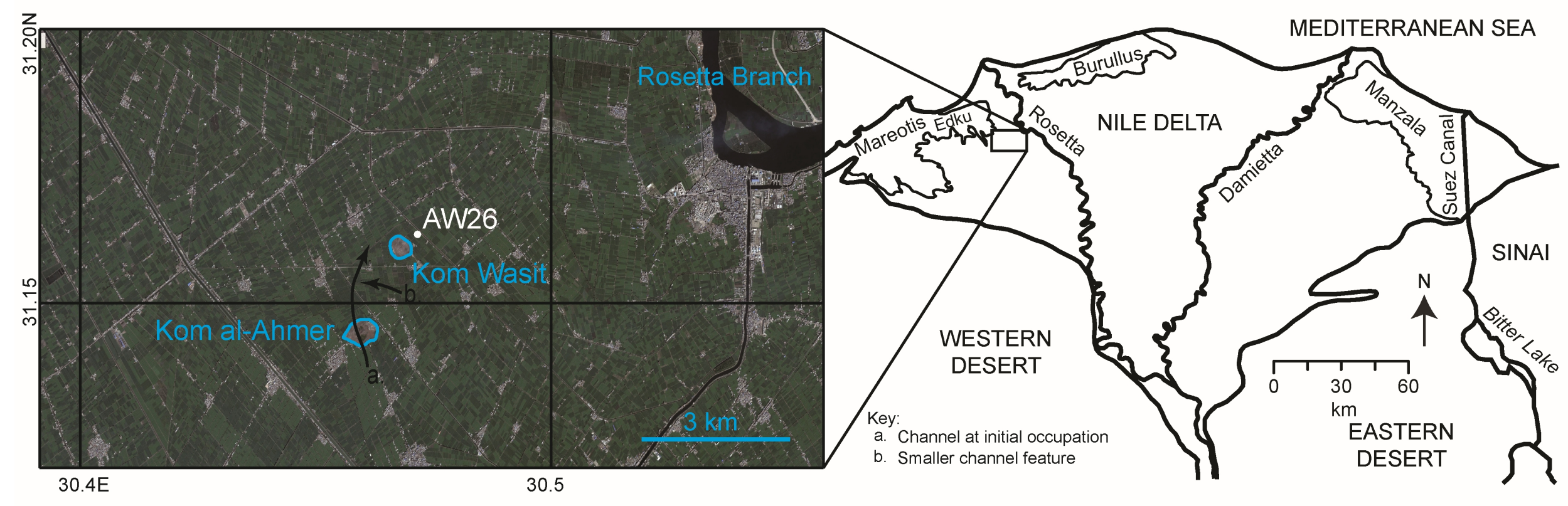




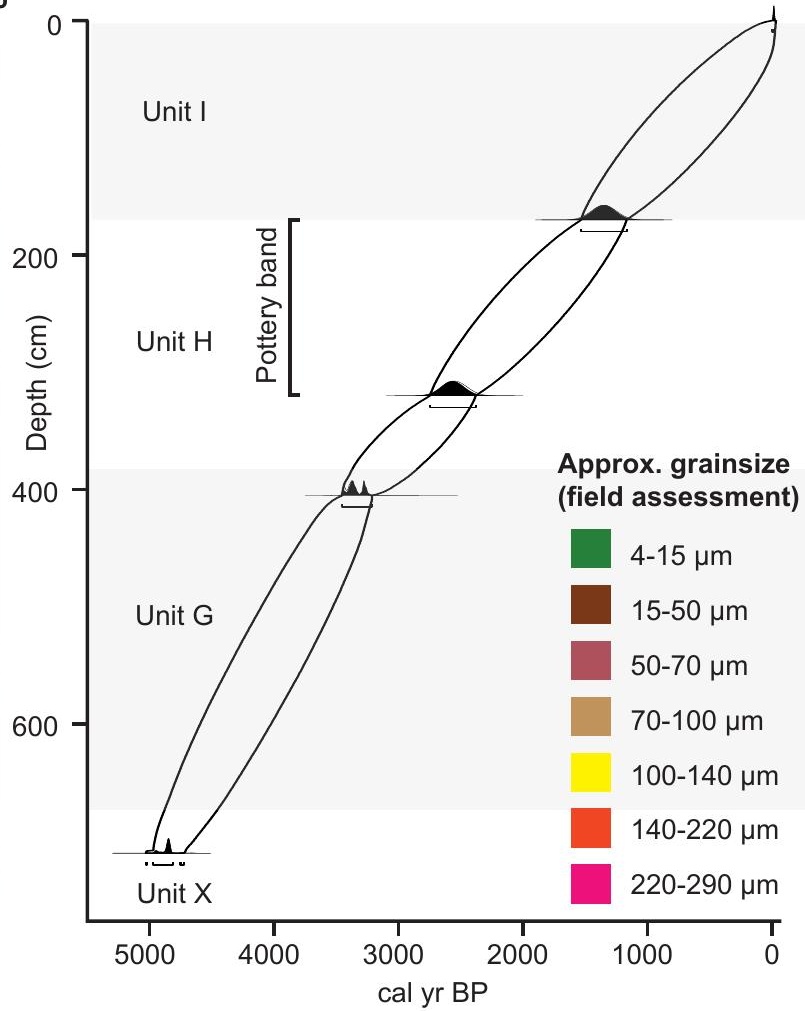



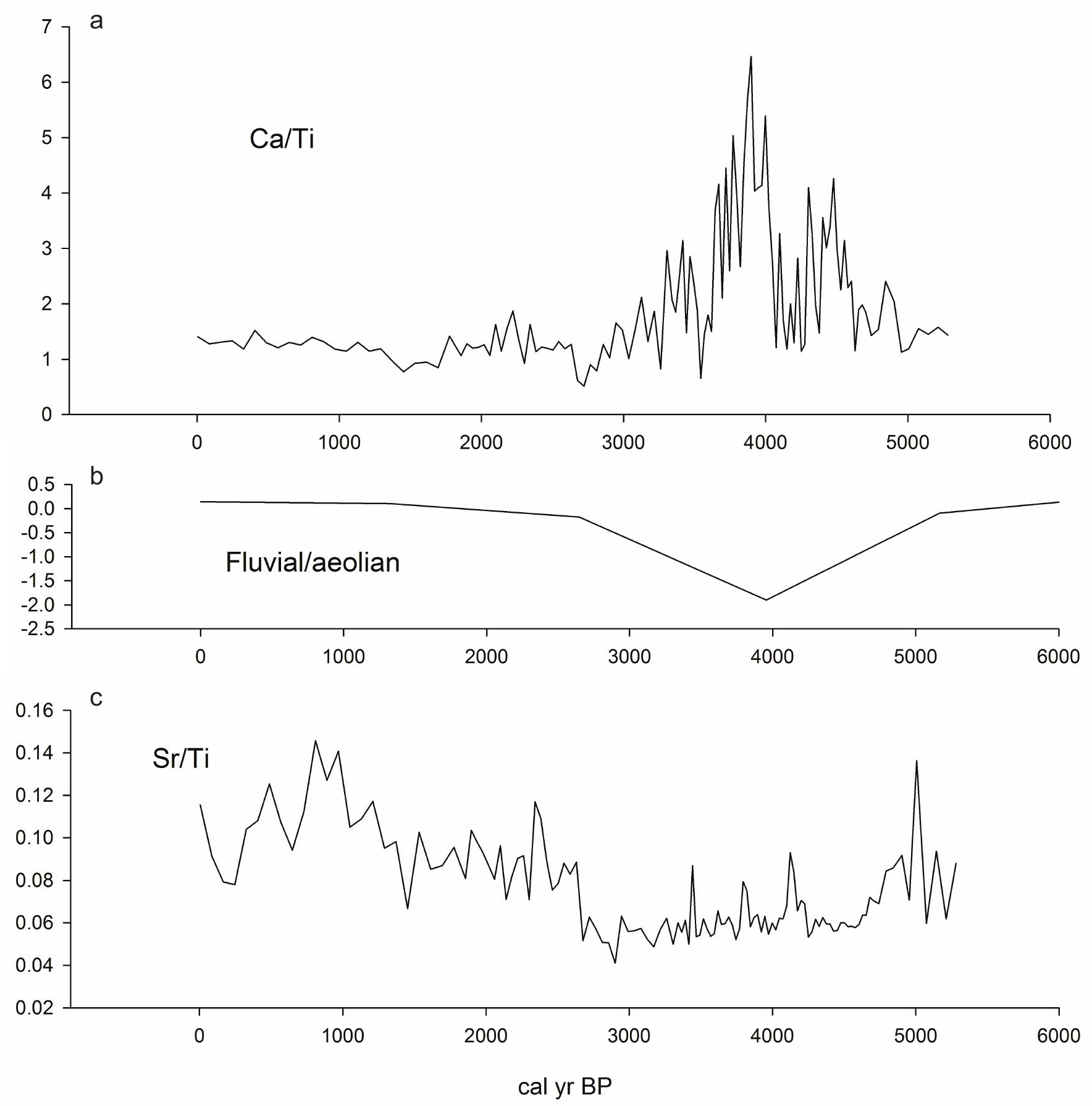


\section{Supplementary Information}

The following figure presents other elemental XRF data retrieved during the analysis.

The data presented for $\mathrm{Ni}, \mathrm{Cu}, \mathrm{Mo}, \mathrm{Co}, \mathrm{Ba}, \mathrm{Ag}, \mathrm{Cd}$ and $\mathrm{Sn}$ are likely to be spurious, resulting from statistical noise being amplified and fitted to elemental spectra erroneously during the analysis. These records are presented simply for completeness.

The other four elemental records: $\mathrm{Nb}, \mathrm{Si}, \mathrm{Cl}$ and $\mathrm{Zn}$, are thought to represent a true signal. 

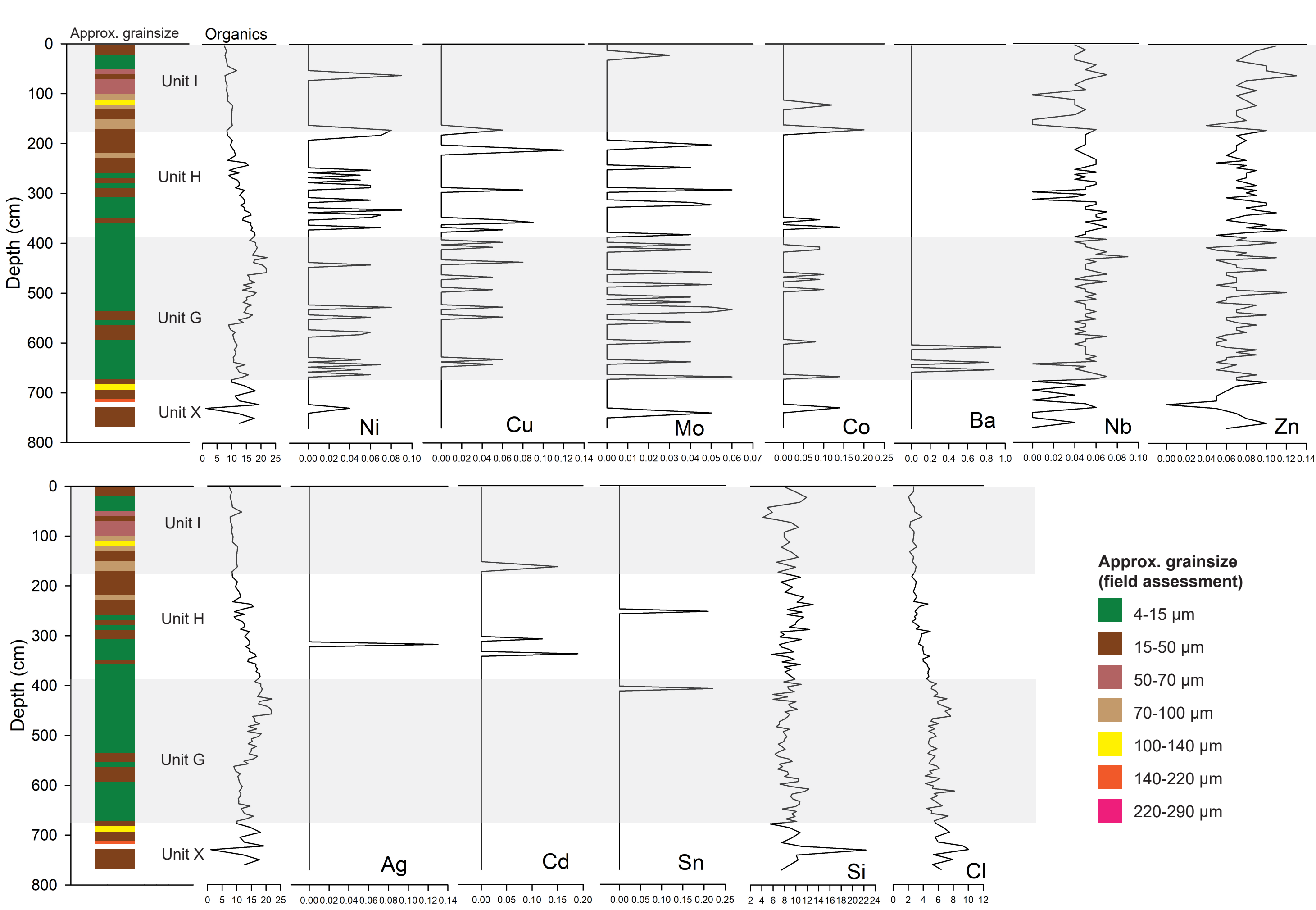

Approx. grainsize (field assessment)

4-15 $\mu \mathrm{m}$

$15-50 \mu \mathrm{m}$

50-70 $\mu \mathrm{m}$

$70-100 \mu \mathrm{m}$

$100-140 \mu \mathrm{m}$

$140-220 \mu \mathrm{m}$

220-290 $\mu \mathrm{m}$

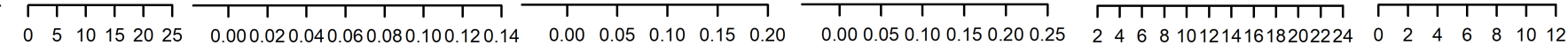

